\title{
PEMBERDAYAAN KELOMPOK IBU PKK DI DESA KERTA KECAMATAN PAYANGAN KABUPATEN GIANYAR BALI SEBAGAI PEMBANTU JUMANTIK UNTUK MENCEGAH INFEKSI DEMAM BERDARAH DENGUE
}

\author{
Sri Masyeni ${ }^{1}$, A.A.G Indraningrat ${ }^{2}$, PA Suryanditha ${ }^{3}$, Agus Santosa ${ }^{4}$ \\ ${ }^{1}$ Fakultas Kedokteran dan Ilmu Kesehatan Universitas Warmadewa masyeniputu@yahoo.com \\ ${ }^{2}$ Fakultas Kedokteran dan Ilmu Kesehatan Universitas Warmadewa anak.indraningrat@gmail.com \\ ${ }^{3}$ Fakultas Kedokteran dan Ilmu Kesehatan Universitas Warmadewa putuaryamd@gmail.com \\ ${ }^{4}$ Fakultas Kedokteran dan Ilmu Kesehatan Universitas Warmadewa omangbabe@yahoo.com
}

\begin{abstract}
ABSTRAK
Demam berdarah dengue (DBD) yang terjadi akibat infeksi virus Dengue merupakan penyakit yang mewabah tiap tahunnya di Bali dan Indonesia pada umumnya. Upaya menekan laju DBD khususnya melalui eradikasi vektor pembawa virus yaitu nyamuk Aedes aegypti perlu terus dilakukan dengan melibatkan peran serta masyarakat secara langsung. Penyuluhan mengenai DBD terhadap kelompok ibu PKK di Desa Kerta, Kecamatan Payangan, Kabupaten Gianyar, Provinsi Bali telah dilaksanakan dengan hasil yang memuaskan. Metode yang digunakan adalah presentasi dan diskusi melalui tatap muka. Hasil penyuluhan menunjukkan peningkatan pemahaman ibu-ibu PKK terhadap DBD dan upaya pencegahannya. Sebagai tindak lanjut kegiatan pengabdian ini, tim pembantu Jumantik dari anggota PKK Desa Kerta, Kecamatan Payangan telah dibentuk. Tim ini diharapkan berperan aktif dalam memonitoring dan meminimalisir tempat berkembang biak jentik nyamuk Aedes aegypti, serta secara aktif mensosialisasikan pencegahan DBD di lingkungan tempat tinggal mereka.
\end{abstract}

Kata Kunci : pemberdayaan, PKK, pembantu jumantik, dengue

\section{PENDAhULUAN}

Infeksi oleh virus dengue (VD) sampai saat ini masih menjadi penyebab utama morbiditas di daerah tropis dan subtropis, serta secara global diperkirakan terjadi kurang lebih 50 juta infeksi per tahun (Simmins et al, 2012). Kasus infeksi VD menyebabkan sekitar 20.000 kematian per tahun (Guzman et al, 2010). Selama bulan Oktober-Desember 2014 jumlah kasus DBD yang terdata di Indonesia adalah 23.882 kasus (Kemenkes, 2017).

Kasus DBD di Bali tidak hanya menjangkiti penduduk lokal, namun juga dilaporkan terjadi pada wisatawan asing (Masyeni et al, 2018). Berbeda dengan kasus DBD pada penduduk lokal, gejala infeksi DBD pada wisatawan asing pada umumnya lebih ringan. Meskipun demikian, beberapa 
wisatawan harus memperpanjang ijin tinggal di Bali akibat tidak layak terbang. Maka dari itu, sebagai daerah utama tujuan wisata, penanganan DBD perlu mendapatkan prioritas karena dapat berpengaruh langsung pada tingkat kunjungan wisatawan.

Pencegahan DBD dilakukan salah satunya melalui pembentukan petugas pemantau Jentik nyamuk (Jumantik) Aedes aegypti untuk memantau dan mengeliminasi jentik nyamuk yang hidup di lingkungan tempat tinggal masyarakat. Sampai saat ini petugas sudah menjalankan tugasnya, namun terkendala dengan jumlah personel dan ruang lingkup monitoring, akibatnya kasus infeksi DBD di Bali tetap tinggi. Maka dari itu perlu dikembangkan pendekatan lain untuk melibatkan masyarakat dalam memantau dan membantu kerja Jumantik.

Ibu-ibu PKK merupakan kelompok masyarakat yang secara aktif bersinggungan dengan kondisi tempat tinggal di suatu desa dan terlibat langsung dalam kegiatan sosial kemasyarakatan. Maka dari itu ibu-ibu PKK sangat ideal untuk menjadi kelompok pembantu Jumantik mengingat mereka memiliki akses untuk menjangkau anggota masyarakat di lingkungan sekitar. Desa Kerta adalah bagian dari Kecamatan Payangan yang merupakan salah satu daerah tujuan wisata di Kabupaten Gianyar. Dalam kegiatan pengabdian ini, kelompok ibu-ibu PKK di Desa Kerta, Kecamatan Payangan dilatih sebagai pembantu Jumantik untuk aktif menyosialisasikan bahaya DBD serta mengeradikasi jentik nyamuk Aedes aegypti di lingkungan tempat tinggal mereka.

\section{METODE PELAKSANAAN}

Kegiatan pelatihan pembantu Jumantik di Desa Kerta, Kecamatan Payangan, Kabupaten Gianyar, Bali dilakukan dengan metode sebagai berikut:

1. Pelatihan metode pencegahan infeksi DBD diberikan oleh tim pengabdi Fakultas Kedokteran dan Ilmu Kesehatan (FKIK) Universitas Warmadewa (Unwar) yang meliputi pemberian pre dan post test untuk menguji pemahaman peserta, pemaparan slide presentasi tentang siklus hidup nyamuk Aedes aegypti, gejala DBD dan upaya pencegahannya, pemutaran video terkait DBD dan focus group discussion dengan ibu-ibu PKK yang terpilih sebagai pembantu Jumantik di Desa Kerta Kecamatan Payangan Gianyar.

2. Tim Pengabdi FKIK Unwar memberikan simulasi tentang identifikasi, pencatatan dan pelaporan barang-barang rumah tangga yang berpotensi menjadi tempat perindukan sarang jentik nyamuk Aedes aegypti.

3. Penyerahan flyer mengenai cara-cara pencegahan infeksi virus DBD, alat tulis dan log book kepada para pembantu Jumantik untuk sarana monitoring dan sosialisasi kepada warga Desa Kerta Payangan Gianyar.

4. Tim pengabdi FKIK Unwar secara kontinu berkomunikasi dengan kader pembantu pemantau jentik tentang perkembangan monitoring jentik dan kegiatan sosialisasi terkait eradikasi jentik nyamuk kepada warga di Desa Kerta Payangan Gianyar. 


\section{HASIL DAN PEMBAHASAN}

Tim pengabdi FKIK Unwar menginisiasi rencana pengabdian melalui diskusi dan brainstorming dengan ketua PKK Desa Kerta, Kecamatan Payangan, Gianyar sebagai mitra dalam kegiatan PKM terkait isu kesehatan yang mengemuka di lingkungan sekitar mereka. Tatap muka dan koordinasi dilakukan sebanyak tiga kali yang mengerucut pada upaya mengedukasi masyarakat tentang bahaya DBD, upaya mengeradikasi jentik nyamuk di lingkungan tempat tinggal warga Desa Kerta dan membentuk tim pembantu Jumantik untuk membantu monitoring jentik nyamuk di perumahan warga. Hasil tatap muka menyimpulkan kegiatan penyuluhan dan pelatihan diberikan oleh tim pengabdi FKIK Unwar pada hari Kamis, 26 September 2019 pukul 11.00 WITA - selesai bertempat di salah satu rumah Ibu PKK di Desa Kerta, Payangan.

Kegiatan diawali dengan pemberian pretest terkait pemahaman dasar akan DBD yang meliputi agen penginfeksi, vektor penyebar dan gejala penyakit. Selanjutnya dilakukan pemaparan melalui sarana slide presentasi dan pemutaran video tentang DBD yang menekankan pentingnya penerapan metode $3 \mathrm{M}$ (menguras, menutup dan mengubur) terhadap barang-barang rumah tangga yang berpotensi menjadi tempat berkembangnya jentik nyamuk. Pemaparan materi diikuti dengan diskusi terkait pengalaman para peserta penyuluhan tentang DBD di lingkungan sekitar mereka. Selanjutnya para kader terpilih di uji pemahamannya akan materi penyuluhan dengan pemberian post-test yang menunjukkan peningkatan skor yang signifikan dari rata-rata nilai pre-test sebesar 25 menjadi rata-rata nilai 80 setelah dilakukan post-test. Hasil ini menunjukkan para kader sudah memiliki pemahaman yang baik akan materi penyuluhan yang diberikan dan akan mampu berperan sebagai tim pembantu Jumantik. Dokumentasi saat penyuluhan ini dapat dilihat pada Gambar 1 dan 2 .

Tim pengabdi juga memberikan deskripsi tugas pembantu Jumantik yang meliputi pencatatatan tempat hidup jentik nyamuk di wilayah tempat tinggal para kader dan penerapan 3M untuk menekan laju pertumbuhan jentik nyamuk. Monitoring dan pendampingan secara berkala dilakukan oleh tim pengabdi FKIK Unwar untuk mengetahui progress pembantu Jumantik dan kendala yang dihadapi para kader ini dilapangan. Secara rutin seminggu sekali, pembantu Jumantik diminta melaporkan hasil observasi mereka di lingkungan perumahan warga di Desa Kerta kepada tim pengabdi FKIK Unwar terkait barang rumah tangga yang potensial menjadi sarang jentik nyamuk. Tim pembantu Jumantik juga diwajibkan untuk melaporkan hasil monitoring mereka kepada tim Jumantik tingkat kecamatan untuk mendapatkan dukungan dan pendampingan lanjut jika dirasa perlu.

\section{KESIMPULAN DAN SARAN}

Secara umum hasil pengabdian ini sudah menemui sasaran ditandai dengan peningkatan pemahaman para kader pembantu Jumantik 
akan gejala DBD dan upaya pencegahannya. Berdasarkan hasil PKM ini, diharapkan peran pembantu Jumantik akan berlangsung secara berkesinambungan dalam upaya menekan angka infeksi virus Dengue di masyarakat, khususnya di desa Kerta, Kecamatan Payangan, Gianyar.

\section{UCAPAN TERIMA KASIH}

Ucapan terimakasih disampaikan kepada Dekan Fakultas Kedokteran dan Ilmu Kesehatan Universitas Warmadewa beserta Ketua Unit Penelitian dan Pengabdian Masyarakat (UP2M) FKIK Unwar atas dukungan finansial dan fasilitas yang diberikan sejak penulisan proposal hingga pelaksanaan kegiatan sehingga PKM ini dapat terselenggara dengan baik.

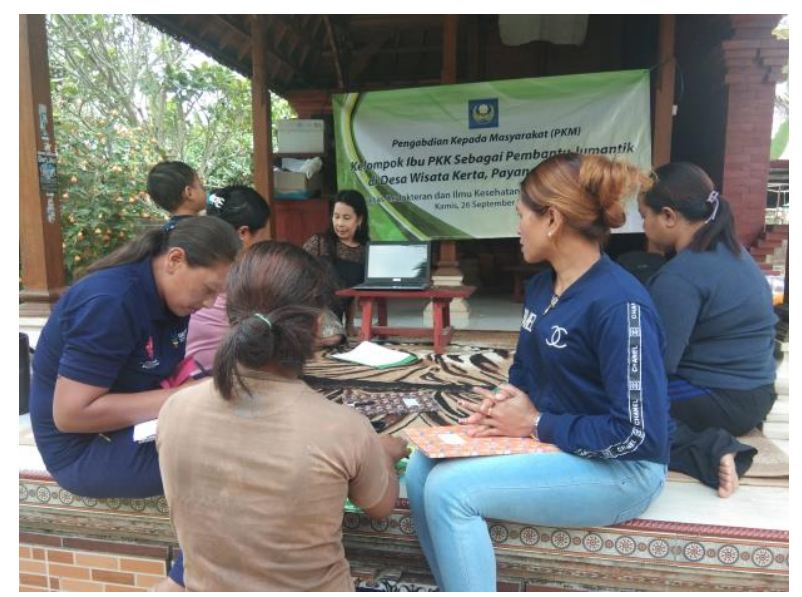

Gambar 1 : Pemberian materi tentang DBD oleh tim pengabdi FKIK Unwar kepada ibu-ibu PKK yang akan menjadi pembantu Jumantik di Desa Kerta, Kecamatan Payangan, Gianyar

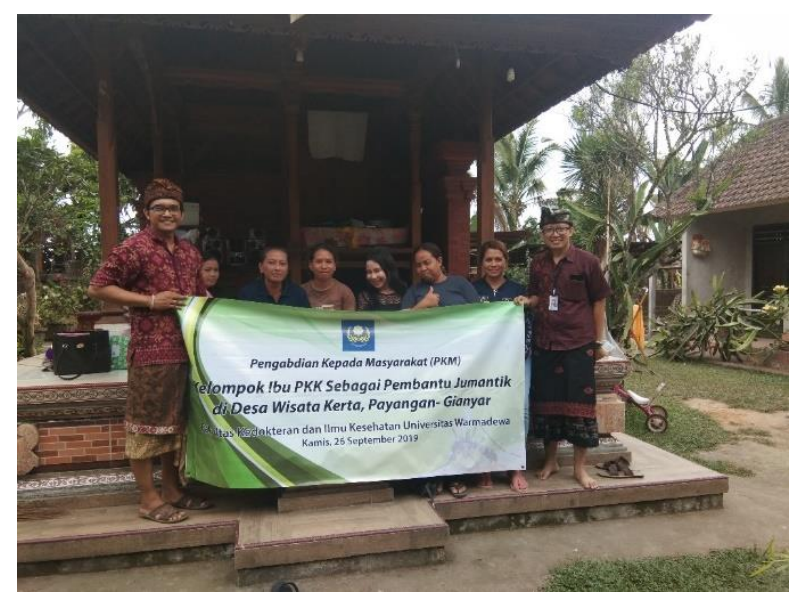

Gambar 2 : Foto tim pengabdi FKIK Unwar bersama para pembantu Jumantik di Desa Kerta, Kecamatan Payangan, Gianyar. 


\section{DAFTAR PUSTAKA}

Guzman MG, Halstead SB, Artsob H, Buchy

P, Farrar J, Gubler DJ, et al. Dengue: a continuing global threat. Nat Rev Microbiol. 2010 Dec;8(12 Suppl):S716.

Kemenkes. Profil Kesehatan Indonesia Tahun 2016. Kementerian Kesehatan RI. 2017. 431 p.

Masyeni S, Yohan B, Somia IKA, Myint KSA, Sasmono RT. Dengue infection in international travellers visiting Bali, Indonesia. J Travel Med. 2018;25(1):tay061.

Simmons CP, Farrar JJ, Nguyen van VC, Wills B. Dengue. N Engl J Med [Internet]. 2012;366(15):1423-32. Available from: http://www.ncbi.nlm.nih.gov/pubme $\underline{\mathrm{d} / 22494122}$ 